\title{
CONSOLIDATION IN MASS TORT LITIGATION
}

A mass tort, such as a plane crash, gives rise to numerous claims. While varied, they are all related to a single fact situation. The desirability of litigating all such claims together appeals strongly to defendants interested in reducing the number of actions they must defend and to courts concerned with convenience and economy in judicial administration. The problem of reducing the number of actions arising from a mass tort can be partially solved by the claimants themselves through permissive joinder under Rule 20(a) of the Federal Rules of Civil Procedure. 1 But where numerous plaintiffs file separate actions, it would be desirable to have a procedural method to compel them to litigate together. This comment will explore the problems involved in using consolidation under Rule 42(a) of the Federal Rules of Civil Procedure to achieve this end.

Rule 42(a) provides:

When actions involving a common question of law or fact are pending before the court, it may order a joint hearing or trial of any or all the matters in issue in the actions; it may order all the actions consolidated; and it may make such orders concerning proceedings therein as may tend to avoid unnecessary costs or delay. 2

1 FED. R. CIV. P. 20(a): "All persons may join in one action as plaintiffs if they assert any right to relief jointly, severally, or in the alternative in respect of or arising out of the same transaction, occurrence, or series of transactions or occurrences and if any question of law or fact common to all of them will arise in the action. All persons may be joined in one action as defendants if there is asserted against them jointly, severally, or in the alternative, any right to relief in respect of or arising out of the same transaction, occurrence, or series of transactions or occurrences and if any question of law or fact common to all of them will arise in the action. A plaintiff or defendant need not be interested in obtaining or defending against all the relief demanded. Judgment may be given for one or more of the plaintiffs according to their respective rights to relief, and against one or more defendants according to their respective liabilities."

An alternative way to reduce the amount of litigation arising from a mass tort is to conduct a model trial. Like permissive joinder, this procedure depends on the willingness of the plaintiffs to adopt it, because a model trial rests on an agreement among parties on both sides that determination of common issues in one representative trial shall be binding on all of them. See In re Texas City Disaster Litigation, 197 F.2d 771 (5th Cir. 1952), aff'd sub nom. Dalehite v. United States, 346 U.S. 15 (1953); Clark v. United States, 13 F.R.D. 342 (D. Ore. 1952).

2 FED. R. Civ. P. 42(a). For general treatment of this rule, see 5 MOORE, FEDERAL PRACTICE Tf 42.02 (2d ed. 1951); 35B C.J.S. Federal Civil Procedure $\$ 916$ (1960). For a discussion of the law of consolidation in New York, see Note, Procedure: Consolidation and Joinder of Actions Against Multiple Parties in New York, 43 CoRNeLL L.Q. 709 (1958).

Rule 42(a) was preceded by Act of July 22, 1813, ch. 14, § 3, 3 Stat. 21: "[W] causes of like nature, or relative to the same question shall be pending before a court of the United States or of the territories thereof, it shall be lawful for the court to make such orders and rules concerning proceedings therein as may be conformable to the principles and usages 
The courts exercise broad discretion in making orders pursuant to this rule, ${ }^{3}$ consolidation being permitted as a matter of convenience and economy in judicial administration. 4 The efficacy of the rule is easily seen. By allowing the proofs on common questions of fact in one action to stand as the proofs in others, and by allowing one decision on common questions of law to be decisive in all actions, duplication of effort is avoided, the time of courts, counsel, parties and witnesses is conserved, and costs are substantially reduced. 5

Essentially, the decision whether or not to grant a motion to consolidate in a particular case is predicated on a process of balancing the interests of convenience against the possibilities of prejudice. Although all motions under 42(a) involve such a balancing process, the mass tort presents some special problems. These problems can best be analyzed by contrasting the mass tort situation to the situation where fewer cases are sought to be consolidated. This analysis will disclose that the best compromise between the diverging pressures of convenience and prejudice in a mass tort case is to consolidate only on the issue of liability, leaving the damage issues to separate trials. This solution, however, is not suitable in all situations, and in cases where it is impossible to consolidate only on the liability issue the court must decide whether to consolidate the actions for all purposes or deny consolidation altogether. This comment, therefore, concludes with a discussion of the factors affecting that decision.

I.

When only a small number of actions are sought to be consolidated, the court must first decide if they satisfy the test in rule 42(a) of a common question of law or fact. Consolidation will be denied, of course, where the suits

belonging to courts for avoiding unnecessary costs or delay in the administration of justice, and accordingly causes may be consolidated as to the court shall appear reasonable." The act was repealed by the enactment of the Judicial Code of 1948.

Decisions ailowing consolidation under the predecessor of 42(a), based as they are on trial convenience, are good law under rule 42(a), since the rule is based on the principle of trial convenience. 5 MOORE, op. cit. supra at 124 n.7.

3 Gillette Motor Transp., Inc. v. Northern Oklahoma Butane Co., 179 F.2d 711 (10th Cir. 1950); United States v. Knauer, 149 F.2d 519 (7th Cir. 1945), aff'd, 328 U.S. 654 (1946); Yuba Consol. Gold Fields v. Kilkeary, 102 F. Supp. 999 (N.D. Cal. 1952), rev'd on other grounds, 206 F.2d 884 (9th Cir. 1953).

4 MacAlister v. Guterma, 263 F.2d 65 (2d Cir. 1958); National Nut Co. v. Susu Nut Co., 61 F. Supp. 86 (N.D. Ill. 1945); Johnson v. Manhattan Ry., 289 U.S. 479 (1933) (interpreting the predecessor of the present rule).

5 Under the final clause of $42(a)$, relating to orders that may tend to avoid unnecessary costs or delay, the courts have greatly extended the utility of the rule as a means of fostering convenience and economy. Thus, for example, consolidation for pretrial purposes and the appointment of a general counsel is allowed. MacAlister v. Guterma, 263 F.2d 65 (2d Cir. 1958); Rando v. Luckenbach S.S. Co., 25 F.R.D. 483 (E.D.N.Y. 1960). Multiple witness fees are disallowed where there has been a consolidated trial. Reynolds Metals Co. v. Yturbide, 258 F.2d 321 (9th Cir.), cert. denied, 358 U.S. 840 (1958). 
arise from separate transactions between the same parties. ${ }^{6}$ Conversely, where all actions grow out of a single fact situation, such as an automobile collision, 7 the requirement would seem prima facie to be satisfied. Since the rule is worded in the singular, it would seem to require but one common question of law or fact. The courts have recognized that the rule sets a minimal standard and have held that the existence of questions that are not common to all the actions will not prevent consolidation. 8

While the rule may set a minimal standard, a party cannot demand consolidation as a right, 9 even where the actions comply with the standard. Consolidation under rule 42 (a) is permissive and rests with the discretion of the court.10 Recognizing this, some courts have looked for more than minimal compliance with the rule and have required a substantial community of common questions of law or fact before granting a motion to consolidate. Thus, in Journapak Corp. v. Bair, ${ }^{11}$ the District Court for the Southern District of New York denied plaintiff corporation's motion to consolidate an antitrust action with an action for damages arising from an alleged conspiracy to divert business from the plaintiff to competing companies controlled by Bair. The court decided to wait until after the discovery proceedings and pretrial conferences were completed to see whether a sufficient community of facts could be found to warrant consolidating the actions for trial. ${ }^{12}$ This seems to be a reasonable practice, because, if consolidation of a small number of actions is to result in a unit of litigation that is more convenient than separate trials, the actions considered should be capable of reasonably parallel determination. Hence, it is appropriate that courts should, in their discretion, require some substantial community of facts before granting a motion to consolidate. Without this flexibility, the policy of convenience and economy behind rule 42(a) may often be frustrated.

This policy of convenience and economy, with its practical translation into the test of reasonably parallel determination, creates the major problem of

${ }^{6}$ Thorne, Neale \& Co. v. Atlantic Gulf Export Corp., 10 F.R.D. 59 (S.D.N.Y. 1949) (dictum).

7 See Nettles v. General Accident Fire \& Life Assur. Corp., 234 F.2d 243 (5th Cir. 1956); Gillette Motor Transport, Inc. v. Northern Oklahoma Butane Co., 179 F.2d 711 (10th Cir. 1950); Plough v. Baltimore \& O.R.R., 172 F.2d 396 (2d Cir. 1949); Polito v. Molasky, 123 F.2d 258 (8th Cir. 1941), cert. denied, 315 U.S. 804 (1942); Clark v. Elgin, 25 F.R.D. 248 (N.D. Ohio 1960); Hassett v. Modern Maid Packers, Inc., 23 F.R.D. 661 (D. Md. 1959); Gaines v. Racenet, 11 F.R.D. 109 (S.D.N.Y. 1950); Miller v. Sammarco, 9 F.R.D. 215 (N.D. Ohio 1949); Brush v. Harkins, 9 F.R.D. 604 (W.D. Mo. 1949); Poulson v. Louisiana, Ark. \& Tex. Transp. Co., 7 F.R.D. 484 (W.D. La. 1947).

8 See Schreiber Trucking Co. v. Rail Trailer Co., 194 F. Supp. 164 (E.D. Pa. 1961); National Nut Co. v. Susu Nut Co., 61 F. Supp. 86 (N.D. Ill. 1945).

9 See Blume, Free Joinder of Parties, Claims, and Counterclaims, 2 F.R.D. 250, 259.

10 Whiteman v. Pitrie, 220 F.2d 914 (5th Cir. 1955).

1127 F.R.D. 509 (S.D.N.Y. 1961).

$12 I d$. at 511. 
mass tort litigation. In mass tort cases, the minimal test of a common question of law or fact will always be satisfied, since all actions arise out of the same fact situation. However, the discretionary test of reasonably parallel determination may not be met where questions of damages are unique to each plaintiff's case. Thus, in Klager v. Inland Power \& Light Co., 13 the court denied defendant's motion to consolidate for all purposes thirty-two actions for flood damage to property. The court reasoned that the determination of questions of proximate cause and damages to thirty-two plaintiffs would overburden any jury. ${ }^{14}$ This seems to express the court's opinion that the community of issues common to all the cases, when compared with the issues unique to each case, was insufficient to justify granting the motion to consolidate for all purposes. The cases were not capable of reasonably parallel determination. The court did suggest, however, that hearings could be had to determine the propriety of consolidating for pretrial purposes, and for trial of the issues relating to the defendant's negligence. 15

Thus, the Klager case suggests the procedure of consolidating only for questions of liability. In the recent case of Wiener v. United States, 16 the District Court for the Southern District of California tried to use that procedure in twenty-three suits filed after a mid-air collision between an Air Force Saber Jet and a United Air Lines passenger plane. 17 Faced with the prospect of defending a multiplicity of suits, defendants, United States and United Air Lines, 18 each made a motion to consolidate. The United States moved for a consolidated trial on the issue of liability only; United moved for consolidation for all purposes. Granting the United States' motion, and denying United's, the court entered an order consolidating the twenty-three cases on the issue of liability, leaving the question of damages to the individual plaintiffs to be tried separately.19 United took an interlocutory appeal under

131 F.R.D. 114 (W.D. Wash. 1939). 14 lbid. 151 F.R.D. at 115.

16192 F. Supp. 789 (S.D. Cal.), rev'd sub. nom. United Air Lines, Inc. v. Wiener, 286 F.2d 302 (9th Cir.), cert. denied, 366 U.S. 924 (1961).

17 For other cases concerning the same accident, see United States v. Wright, 282 F.2d 428 (3d Cir. 1960); United Air Lines, Inc. v. United States, 192 F. Supp. 796 (D. Del. 1961); United Air Lines, Inc. v. United States, 186 F. Supp. 824 (D. Del. 1960); United Air Lines, Inc. v. United States, 186 F. Supp. 828 (D. Del. 1960); United Air Lines, Inc. v. United States, 26 F.R.D. 213 (D. Del. 1960); United Air Lines, Inc. v. United States, 192 F. Supp. 795 (D. Del. 1959).

Most of these cases concern the attempt of the United States to transfer litigation under 28 U.S.C. \$1404(a) (1958) from the District of Delaware to the District of Nevada, where other similar actions were being litigated. There is authority to the effect that the possibility of consolidation in the transferee district is a factor to consider in ruling on a motion to transfer. See Winsor v. United Air Lines, 153 F. Supp. 244 (E.D.N.Y. 1957); Aircraft Marine Prods., Inc. v. Burndy Eng'r Co., 96 F. Supp. 588 (S.D. Cal. 1951); Apex Elec. Mfg. Co. v. Sears, Roebuck \& Co., 87 F. Supp. 533 (S.D. Ohio 1949). Under the circumstances presented in these cases, however, the motion to transfer was denied.

18 Hereinafter referred to as United.

19192 F. Supp. 789, 793 (S.D. Cal. 1961). 
1292(b).20 The Ninth Circuit reversed the order of the district court and remanded, holding that since some of the plaintiffs had asked for exemplary damages, which are dependent on the degree of culpability of each defendant, the issues of liability and damages were not distinct and separable enough to permit separate trials of damages and liability without injustice. 21 The court expressly reserved the wider question whether the constitutional guarantee of trial by jury prohibits the trial of damages to a jury that did not decide the issue of liability.22

The trial court in this case was faced with a situation similar to the one presented to the court in Klager. The issue of exemplary damages, like the question of proximate cause, is unique to each claimant's case. In such situations the convenience and economy, fostered by granting consolidation, appears insignificant in light of the complexity added to the jury's task. However, in Weiner, as in Klager, the negligence issues were common to all the actions. By consolidating only with respect to liability, the court hoped to litigate all the parallel issues together while avoiding the complexities that arise out of trying many dissimilar issues to the same jury. This would seem to be a highly desirable compromise in many cases. Such a procedure secures the benefits of consolidation for all purposes but avoids many of the problems of a mass trial. The procedure is supported, moreover, by the recent trend toward litigating liability separately from damages in tort cases. 23 It is also supported by the prior practice under 42(a) of consolidating only for the purpose of determining some of the issues involved in the cases. 24

It would thus appear that the procedure of consolidating only on the issue - of liability is a desirable compromise between the extremes involved in granting consolidation for all purposes, on the one hand, and denying it altogether on the other. This procedure can be followed in the usual mass tort case where damages can be ascertained without reference to the evidence concerning lia-

2028 U.S.C. § 1292(b) (1958).

21 Rodella v. United States, 286 F.2d 302, 306 (9th Cir. 1960).

22 Ibid. This question was also reserved by the Seventh Circuit in Hosie v. Chicago \& N.W. Ry., 282 F.2d 639 (7th Cir. 1960). There is authority, however, to the effect that trial of liability and damages by two different juries is not unconstitutional. In O'Donnell v. Watson Bros. Transp. Co., 183 F. Supp. 577,585 (N.D. Ill. 1960), the court stated: "[T] he trial judge may, in his discretion, order one jury to decide upon the liability of the defendant and the same or another jury to determine the damages of the plaintiffs. . . The right to a trial by jury does not require that all issues be determined by the same jury and severance of the issues is not violative of any constitutional guarantee."

${ }^{23}$ See Hosie v. Chicago \& N.W. Ry., 282 F.2d 639 (7th Cir. 1960). See also Note, 74 HARV. L. REv. 781 (1961).

24 See United States v. Holtz, 54 F. Supp. 63 (N.D. Cal. 1944), aff'd sub nom. Kuehn v. United States, 162 F.2d 716 (9th Cir. 1947) (twenty-eight actions for cancellation of naturalization certificates consolidated for the sole purpose of receiving evidence as to the principles and practices of the German-American Bund); Hotel George V v. McLean, 1 F.R.D. 241 (D.D.C. 1940) (four contract actions consolidated only with reference to the common defense of mental incapacity). 
bility. As the Weiner case shows, however, this procedure cannot justly be applied in all situations. The Ninth Circuit was correct in reversing in that case. Exemplary damages are so intimately related to the question of liability that fairness to the plaintiffs demands that the jury that decides damages have the benefit of the evidence concerning liability.

II.

In mass tort cases such as Weiner that cannot be handled by consolidating only with respect to liability, the trial court must decide whether to order separate trials or consolidate for all purposes. The first alternative seems wasteful of the time of courts which already have overcrowded dockets. It is also necessary to consider the notion of fairness to the defendants who want to avoid a multiplicity of suits. The latter alternative involves the possibility of creating a unit of litigation so complex that the rights of the parties may be prejudiced by jury confusion. The ultimate choice between separate trials and a consolidated trial must depend on a further examination of the test of reasonably parallel determination, and on the effectiveness of the techniques which the courts have at their disposal to cope with the complexities of mass trials.

Where a small number of cases are sought to be consolidated, considerations of convenience and economy lead quite justifiably to the conclusion that the test of reasonably parallel determination should govern the court's discretion. But where a large number of actions are involved, this test leads to the conclusion that consolidation should be denied. This is true because the greater the number of claimants with unique claims for damages, the less capable their actions are of reasonably parallel determination. In situations where consolidation on liability only is not possible, the court should not rely on the parallel determination test alone, but should look beyond that test and give appropriate weight to the countervailing consideration of the burden on the defendants in defending a great number of suits. Where the community of issues common to a handful of cases is insufficient to satisfy the parallel determination test, the burden on the defendants will not be great if they must litigate the few common issues a few times, but as the number of actions increases, the burden can become more onerous. In short, it is appropriate for the court to recognize that the purposes of the rule can be promoted as much by consolidating many actions with few common issues as by consolidating a few actions with many common issues.

Thus the convenience factor usually weighs heavily in favor of consolidation for all purposes. This factor, however, must be balanced against the possibility of prejudice resulting from jury confusion. The ultimate decision must, as a consequence, rest squarely on the court's estimation of its ability to simplify and control the complex proceedings in a mass trial.

In general, the problem that faces a court in a mass trial is to insure a proper decision of each plaintiff's case on its own merits. Multiple parties, 
multiple issues and complex fact situations all increase the risk that the merits of one case will become confused by the jury with the merits of another, prejudicing the rights of one or more of the parties. The court must be cautious in exercising its discretion in favor of a mass trial, as it risks reversal on the ground that the sheer size of the trial violated the parties' rights to due process. 25

There are, however, a number of devices at the trial court's disposal to insure fair and orderly proceedings in a mass trial.26 Efficient use of discovery procedures can narrow the scope of the issues that the jury will have to decide. ${ }^{27}$ The pretrial conference 28 is similarly helpful, and also provides a means of establishing a well-organized and economical trial plan which can reduce delay and limit the amount of testimony the jury will have to consider. Once the trial has begun, the court may permit the jury to supplement their memories with written notes, 29 and may also help the jury to evaluate masses of testimony by commenting on the evidence. ${ }^{30} \mathrm{~A}$ careful charge is an essential guide for the jury's deliberations, and the court may consider putting it in writing for the jury if it is long and complicated.31

The court may also require a special verdict or a general verdict with interrogatories. 32 These requirements force the jury to consider discrete questions individually and afford an opportunity to check the jury's verdict for any possible misunderstanding. Finally, in extraordinary situations, the burden on the jury can be substantially lessened through the use of a master. 33

No one of these devices is a panacea. Nor is it possible to devise a formula that will enable the court to determine automatically the propriety of consolidating a large number of actions for all purposes. Such a decision must be made in light of the particular fact situation of each group of cases. It is eminently a matter for judicial discretion. But the existence of the foregoing devices, with the possibility of using them in various combinations, does allow the court to serve the interests of convenience in a consolidated mass trial without prejudicing any party's case.

Aside from multiple parties, multiple issues and complicated fact situations, another factor that increases the complexity of a trial is the trying of some issues to the jury and others to the court. The question thus arises

25 See Gwathmey v. United States, 215 F.2d 148 (5th Cir. 1954).

${ }^{26}$ See generally Note, The Challenge of the Mass Trial, 68 HARv. L. Rev. 1046 (1955).

27 See FeD. R. Crv. P. 26-37.

28 See Fed. R. Crv. P. 16.

${ }^{29}$ See Harris v. United States, 261 F.2d 792 (9th Cir. 1958); Goodloe v. United States, 188 F.2d 621 (D.C. Cir. 1950).

30 See Quercia v. United States, 289 U.S. 466 (1933); Roberts v. United States, 284 F.2d 209 (D.C. Cir. 1960).

31 See Doane v. Jacobson, 244 F.2d 710 (1st Cir. 1957); Carrado v. United States, 210 F.2d 712 (D.C. Cir. 1953); Copeland v. United States, 152 F.2d 769 (D.C. Cir. 1945).

32 See FED. R. CIV. P. 49.

33 See Fed. R. Crv. P. 53. 
whether a court should consolidate cases where the plaintiffs demand a jury with other cases arising out of the same mass tort where the plaintiffs request trial by the court. The Federal Rules of Civil Procedure expressly adopt the practice of determining the form of trial for each issue rather than for the action as a single unit. 34 This fact has been urged in support of the position that consolidation of jury and non-jury cases should be allowed. 35 Some courts, however, have recognized the complexity involved in this practice, and as a consequence have argued that jury cases should not be consolidated with non-jury cases. 36

Neither of these procedures is particularly desirable. Denying consolidation is wasteful since identical issues will be litigated more than once; trying some cases to the court and others to the jury within the same unit of litigation is undesirable because of the creation of needless confusion.

Three other possibilities bear examination. First, the court might consolidate the cases and try them all to the court. This procedure is wholly unacceptable since it deprives those plaintiffs who demand a jury of a constitutionally guaranteed right. 37 Second, the court could consolidate the actions and try them all to the jury. Unlike trial by jury, trial by the court is not constitutionally protected. 38 Use of this procedure has been urged in litigating jury and non-jury claims joined in a single case in admiralty. ${ }^{39}$ It seems a highly attractive alternative because of its simplicity and uniformity. But if the court orders all cases to be tried to the jury, those plaintiffs who requested trial by the court will have a jury forced upon them against their wishes. In this respect, the procedure is inferior to the third alternative which would consolidate all the jury cases and try them first, and then incorporate the record of the jury trial in a consolidated trial of the non-jury cases. 40 The plaintiffs in the non-jury cases should be allowed to participate in the jury trial, and should also be allowed to introduce additional evidence in the non-jury trial.41 This procedure will be particularly effective if the same judge who sat in the jury trial sits in the non-jury trial, although this is not essential.42 This solution has

${ }^{34}$ See FEd. R. Crv. P. 38, 39.

${ }^{35}$ See Sherwood v. United States, 112 F.2d 587 (2d Cir. 1940). See also United States v. Yellow Cab Co., 340 U.S. 543 (1951).

${ }^{36}$ See Gabrielson v. Public Industrials Corp., 8 Fed. R. Serv. 734 (S.D.N.Y. 1944).

37 Cf. Leimer v. Woods, 196 F.2d 828 (8th Cir. 1952).

38 Beacon Theatres, Inc. v. Westover, 359 U.S. 500 (1959); Note, The Right to Non-jury Trial, 74 HARv. L. Rev. 1176 (1961).

39 See Kurland, The Romero Case and Some Problems of Federal Jurisdiction, 73 HARv. L. REv. 817 (1960); Currie, The Silver Oar and All That-A Study of the Romero Case, 27 U. Chr. L. Rev. 1 (1959).

${ }^{40}$ See Whiteman v. Pitrie, 220 F.2d 914 (5th Cir. 1955); Walker v. Loop Fish \& Oyster Co., 211 F.2d 777 (5th Cir. 1954).

41 See Walker v. Loop Fish \& Oyster Co., supra note 40.

42 Ibid. 
the double advantage of preserving the right to a jury trial, while permitting those plaintiffs who so desire to have their cases tried to the court, and of attaining the ends of convenience and economy behind rule 42(a) by avoiding needless litigation of relevant matters incorporated in the jury trial record.

\section{CONCLUSION}

The district courts have developed an extremely flexible practice under rule 42(a). The wide discretion vested in the courts has enabled them to proceed with unusually great freedom in making orders pursuant to the rule. The scope of this freedom is mirrored in the paucity of reversals of orders granting. or denying consolidation. While these orders are reviewable on appeal from a final judgment, they will not be disturbed except for abuse of discretion. 43 Only one case besides Weiner was found that allowed an interlocutory appeal from a consolidation order. 44

Fundamentally, the task of a court faced with a motion to consolidate a large number of cases arising out of a mass tort is to balance the interests of of convenience against the possibilities of prejudice. Usually, an order consolidating the cases only with respect to liability would seem to be a reasonable compromise between these two considerations. But as Weiner shows, this solution cannot be made the general rule since the peculiarities of many situations must be considered by the court in ruling on motions to consolidate. A flexible discretionary rule is thus to be preferred to an inflexible one. It is neither possible nor desirable for courts to treat motions under 42(a) with the cold logic Alice displayed in dealing with Rule Forty-Two in Wonderland. 45 What is required is a constant sensitivity to the equities of individual cases in conjunction with the experience courts have gained in handling juries and in administrating the cases on their dockets.

43 Whiteman v. Pitrie, 220 F.2d 914 (5th Cir. 1955). See also Gwathmey v. United States, 215 F.2d 148 (5th Cir. 1954) (abuse of discretion held to be a denial of due process).

44 See MacAlister v. Guterma, 263 F.2d 65 (2d Cir. 1958) (allowing appeal under the doctrine of Cohen v. Beneficial Industrial Loan Corp., 337 U.S. 541 (1949)). The chances for an interlocutory appeal are slight because of the narrow scope of the Cohen rule and because of the hesitancy of the courts to use $\$ 1292(\mathrm{~b})$. More liberal use of $\S 1292(\mathrm{~b})$ might seem desirable here, since an immediate appeal could materially advance the ultimate termination of the litigation.

45 " 'Rule Forty-two. All persons more than a mile high to leave the court.'

Everybody looked at Alice.

" 'I'm not a mile high,' said Alice.

" 'You are,' said the King.

" 'Nearly two miles high,' added the Queen.

"' 'Well, I shan't go, at any rate,' said Alice; 'besides, that's not a regular rule: you invented it just now.'

" 'It's the oldest rule in the book,' said the King.

" 'Then it ought to be Number One,' said Alice." Carrol, Alice's Adventures IN WONDERLAND 180 (1st. ed. 1865). 